\title{
Pathological and Molecular Biological Features of A Myelopathy Associated with HTLV-1 Infection
}

\author{
Christopher Power, Brian G. Weinshenker, Gregory A. Dekaban, \\ John C.E. Kaufmann, Maureen Shandling and George P.A. Rice
}

\begin{abstract}
We report the pathological and molecular biological findings of human T-cell lymphotropic virus type l (HTLV-1) infection of the spinal cord in a patient with a chronic progressive myelopathy. Light microscopy disclosed loss of myelin and axons, thickening of blood vessels and a lymphocytic cell infiltrate in the spinal cord especially at the cervical and thoracic levels. Electron microscopy confirmed the vascuolar appearance seen with light microscopy but virus particles were not observed. The HTLV-1 gag gene could be amplified (by polymerase chain reaction) from cervical spinal cord tissue while not from elsewhere in the neuroaxis. The presence of HTLV-1 geonomic material in spinal cord tissue has not been previously reported.
\end{abstract}

RÉSUMÉ: Anatomopathologie et biologie moléculaire d'une myélopathie associée à l'infection par HTLV-1. Nous rapportons les constatations anatomopathologiques et les études de biologie moléculaire d'une infection de la moelle épinière par le virus lymphotrophe de type 1 des cellules T humaines (HTLV-1) chez un patient porteur d'une myélopathie progressive chronique. La microscopie conventionnelle a montré une perte de myéline et des axones, un épaississement des vaisseaux sanguins et un infiltrat lymphocytaire de la moelle épiniaire, surtout au niveau cervical et thoracique. La microscopie électronique a confirmé l'apparence vacuolaire observée au microscope conventionnel, sans toutefois mettre en évidence de particules virales. Le gène gag du HTVL-1 a pu être amplifié (par réaction en chaîne au moyen de la polymérase) à partir de tissus provenant de la moelle épinière cervicale, mais non d'autres sites de l'axe nerveux. La présence de matériel génomique du HTLV-1 dans des tissus provenant de la moelle épinière n'a encore jamais été rapportée.

Tropical spastic paraparesis (TSP) has been associated with an infection by Human T-cell Lymphotropic Virus Type 1 (HTLV-1) 1.2 HTLV-1 has been found in the CSF and sera of patients with myelopathies in the Caribbean basin, ${ }^{3}$ Seychelles, ${ }^{4}$ Colombia, ${ }^{5}$ Japan $^{6}$ and North America. ${ }^{7}$ Pathological studies of this condition are scarce.8.9.10,11 To date, the presence of HTLV1 genome in the spinal cords of patients with TSP has not been demonstrated. We present a pathological study of a case of TSP with molecular biological evidence of HTLV-1 infection at the site of pathological changes.

\section{Methods AND Materials}

\section{Case History}

A 46-year-old black Jamaican woman presented with leg stiffness and weakness in 1976. She later developed burning paresthesiae in both legs and mild urinary frequency and urgency. Her previous medical history had been unremarkable as was her family history. Physical examination revealed a moderately severe spastic paraparesis with generalized hyperreflexia and bilateral Babinski responses. She had mild loss of vibration perception in her legs. Her gait was both ataxic and spastic.

A complete myelogram done in 1978 was normal. The spinal fluid revealed 5 lymphocytes per $\mathrm{mm}^{3}$, and an increased IgG-albumin ratio (.58, normal less than .25). Total CSF protein, was normal $(18 \mathrm{mg} / \mathrm{dl})$. A serological test for syphilis was negative.

She died in 1986 of complications of metastatic gallbladder carcinoma. A general autopsy revealed a carcinoma of the bladder, locally metastatic to the liver.

A general and neurological autopsy was performed. Blocks of formalin fixed cerebrum, brain stem, spinal cord and peripheral nerve were embedded in paraffin. Sections weere stained with hematoxylin and eosin, luxol fast blue (LFG), solochrome R/cresyl violet (SCR/CV) and Beilschowsky stains. Some sections were also stained for glial fibrillary acidic protein (GFAP), with an immunohistochemical technique. One cubic mm blocks of formalin fixed paraffin embedded cervical and thoracic spinal cord and subcortical white matter were studied by electron microscopy. This tissue was rinsed in xylene/acetone and embedded in Epon-Araldite. Semi-thin sections were stained with toluidine blue. Ultra thin sections were examined with a Zeiss 109 transmission electron microscope.
\end{abstract}




\section{Immunohistochemistry}

Sections from the proband's neuroaxis, and control tissues including normal CNS tissue and a recrotizing myelopathy were stained using a murine monoclonal antibody directed against the HTLV-1 p19 core protein at dilutions of $1: 5$ to $1: 1000$ with a biotinylated goat antibody to mouse IgG. Controls included HTLV-1 infected T-cell line HUT-102 cells and noninfected $\mathrm{H}-9$ cells (pelleted).

\section{Molecular Biology}

Multiple five micron fixed sections were cut from the paraffin blocks and the DNA was extracted from the proband and 2 controls. ${ }^{10}$ A sham extraction was performed in parallel.

The polymerase chain reaction (PCR) technique was conducted as previously described. ${ }^{12}$ The sequence and specifications of the primers and probes for the p24 and pol gene have been described elsewhere. ${ }^{12}$ The reaction products were separated in $1 \%$ aragrose and transferred to Zeta Probe nylon paper (BIORAD). These blots were hybridized with a p32 end labeled probe and then washed as previously described. ${ }^{12,13}$

\section{RESULTS}

\section{Gross Pathological Findings}

The fresh brain weighed 1200 gms. After fixation, the brain, meninges and spinal cord were normal in appearance.

\section{Light and Electron Microscopy}

Microscopic changes were most prominent in the spinal cord, especially in the thoracic and cervical levels. Leptomeningeal thickening was widespread over the spinal cord and brain stem. A lymphocytic cell infiltrate was present in the meninges, in the blood vessel walls and in the Virchow-Robin spaces. Small lymphocytic infiltrates could be identified within the posterior and lateral columns of the spinal cord which were less prominent in the lumbar and sacral levels. Blood vessels appeared to be thickened and increased in number within the lateral columns (Figure 1). The posterior and lateral columns were pale when stainned with SCR/CV and LFB and had a vacuolar appearance which was most marked at the thoracic and cervical levels. Axonal density was decreased in these regions of reduce myelination (Figure 2 - Bielschowsky stain). Gliosis was prominent within these two columns as shown by staining with GFAP. Within the brain stem there was some pallor of the descending tracts and this was most prominent when the pons was stained with SCR/CV and LFB. A reduced number of motor neuron cell bodies was

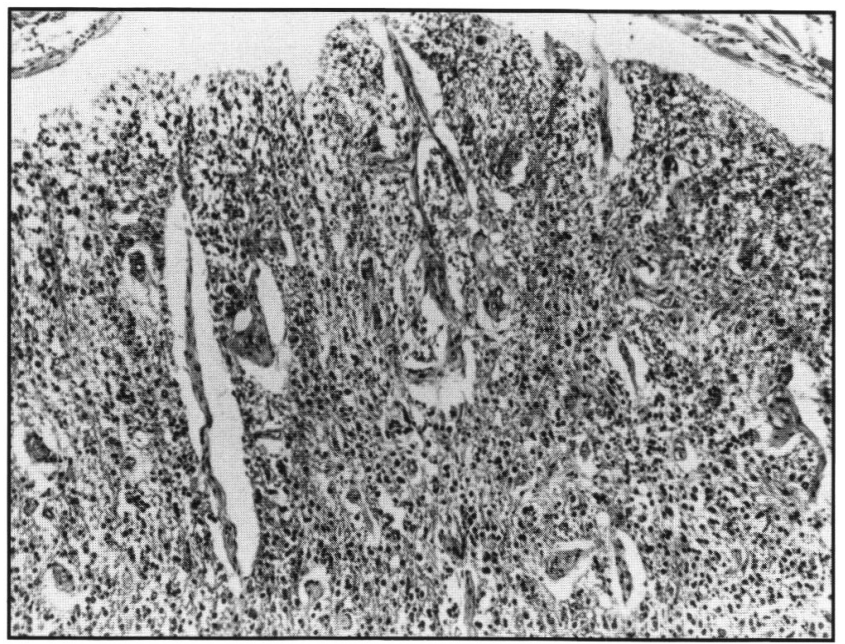

Figure I - Blood vessel walls appeared thickened and increased in number with the lateral columns. (Hematoxylin and Eosin, $x$ 120). observed in the ventral horns in the cervical sections. The dorsal root ganglia showed cell loss without inflammation. Peripheral nerve sections demonstrated fewer than normal large myelinated fibres without demyelination or inflammation. The cerebrum (cortex, white matter and diencephalon) was normal. Foamy macrophages were not observed.

Although fixation was suboptimal, electron microscopy revealed that the myelinated axons were normal in the subcortical white matter but prominent vacuolation was seen in all spinal cord sections with myelin swelling, particularly the lateral columns (Figure 3). Virus particles were not identified.

\section{Immunohistochemistry}

The HTLV-1 p19 specific monoclonal antibody did not react with tissue sections from the proband, normal CNS or the necrotizing myelopathy. There was a strong reaction with HTLV-1 infecvted HUT- 102 cells but not with the uninfected cells.

\section{Molecular Biology}

The results of this experiment are shown in Figure 4 . We were able to amplify the expected 623 base product from the gag gene in the positive control material (DNA from leukocytes of patients with TSP - lanes 11 and 12). We could not amplify

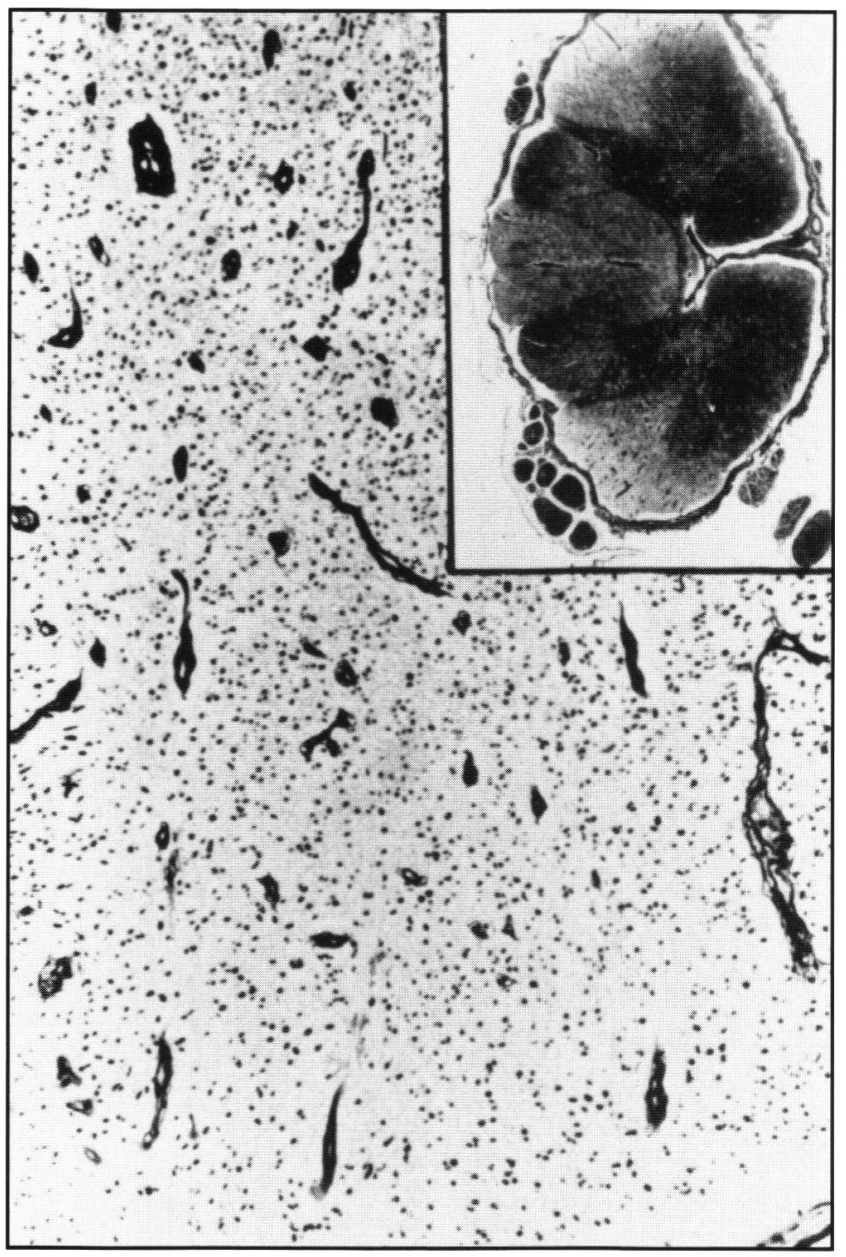

Figure $2-A$ reduced number of axons were observed in the lateral columns (Bielchow'sky, $x$ 100). The inset show's pallor with a reduced number of axons in lateral and posterior columns (Bielchowsky, x 16). 
this fragment in DNA extracted from paraffin embeded blocks of brain nor in spinal cord from healthy normals (lanes 1 and 2). In the DNA from the cortex, midbrain and thoracic spinal cord of the proband, we were unable to identify the fragment (lanes 3,5 and 6). However in the cervical spinal cord (lane 4) we were able to identify the appropriate fragment.

DNA extracted from the progressive necrotizing myelopathy failed to produce this band. Sham DNA extractions (lanes 8 and 9) and a water control (lane 10) were also negative. We were unable to amplify fragments from the pol gene due to inadequate quantities of DNA.

\section{DisCUSSION}

The major pathologic finding was a loss of myelin and axonal loss throughout the spinal cord, predominantly at the cervical level. The thickened blood vessel walls and widespread lymphocytic infiltrates suggested an inflammatory process. The pathological features of this case bear a strong resemblance to previous descriptions. ${ }^{8} .9$ Electron microscopic features confirmed the vacuolar appearance seen with light microscopy. We could not identify viral particles although Liberski et al. have reported observation of viral particles. 15 This may have been due to sub-

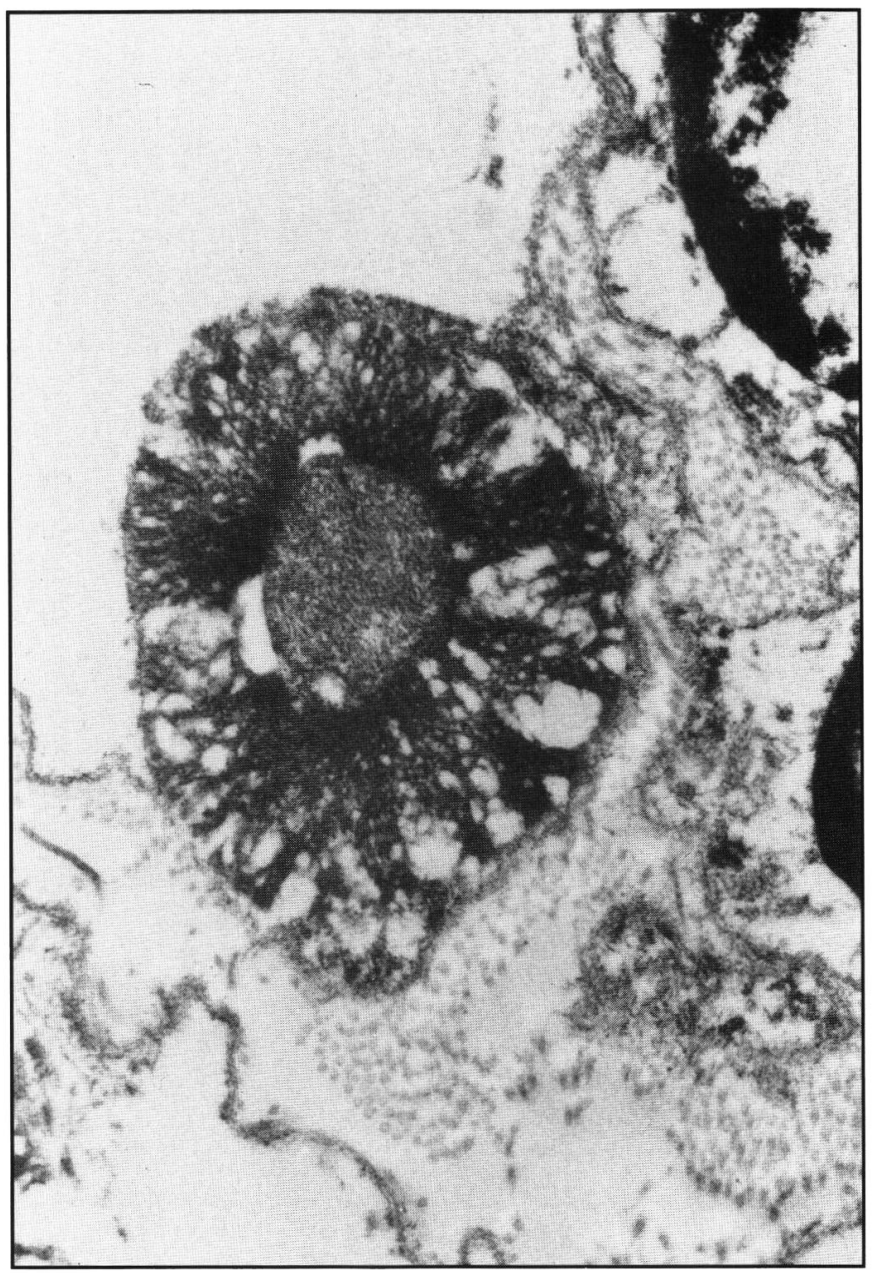

optimal tissue preparation or alternatively free virons were not present in the spinal cord. Viral antigens could not be demonstrated in our spinal cord using a monoclonal antibody. Similar findings have been previously reported. ${ }^{9}$ This inability to show viral antigens in TSP spinal cords might imply tissue damage by fixation methods.

Earlier studies have shown immunological evidence of viral presence in the CSF and spinal cords of TSP patients but viral genomic material has not been directly demonstrated ${ }^{2,11} \mathrm{~A}$ sensitive gene amplification technique permitted identification of an HTLV-1 genomic sequence within the cervical cord in this study. This same sequence could not be amplified from other parts of the neuroaxis which were less affected pathologically. The same sequence could not be detected in healthy spinal cord tissue nor in a patient with a necrotizing myelopathy. The colocalization of the major pathological changes in the spinal cord with PCR amplifable viral sequences suggests that ongoing virus infection plays a role in the myelopathy. The mechanism of viral action may be by an indrect means through lymphocytes or macrophages which are known to be infected with HTLV-1 as proposed by others. "I In light of our findings of the co-existence of the site of major pathology with viral presence, a more plausible mechanism of action is direct viral infection of glia with

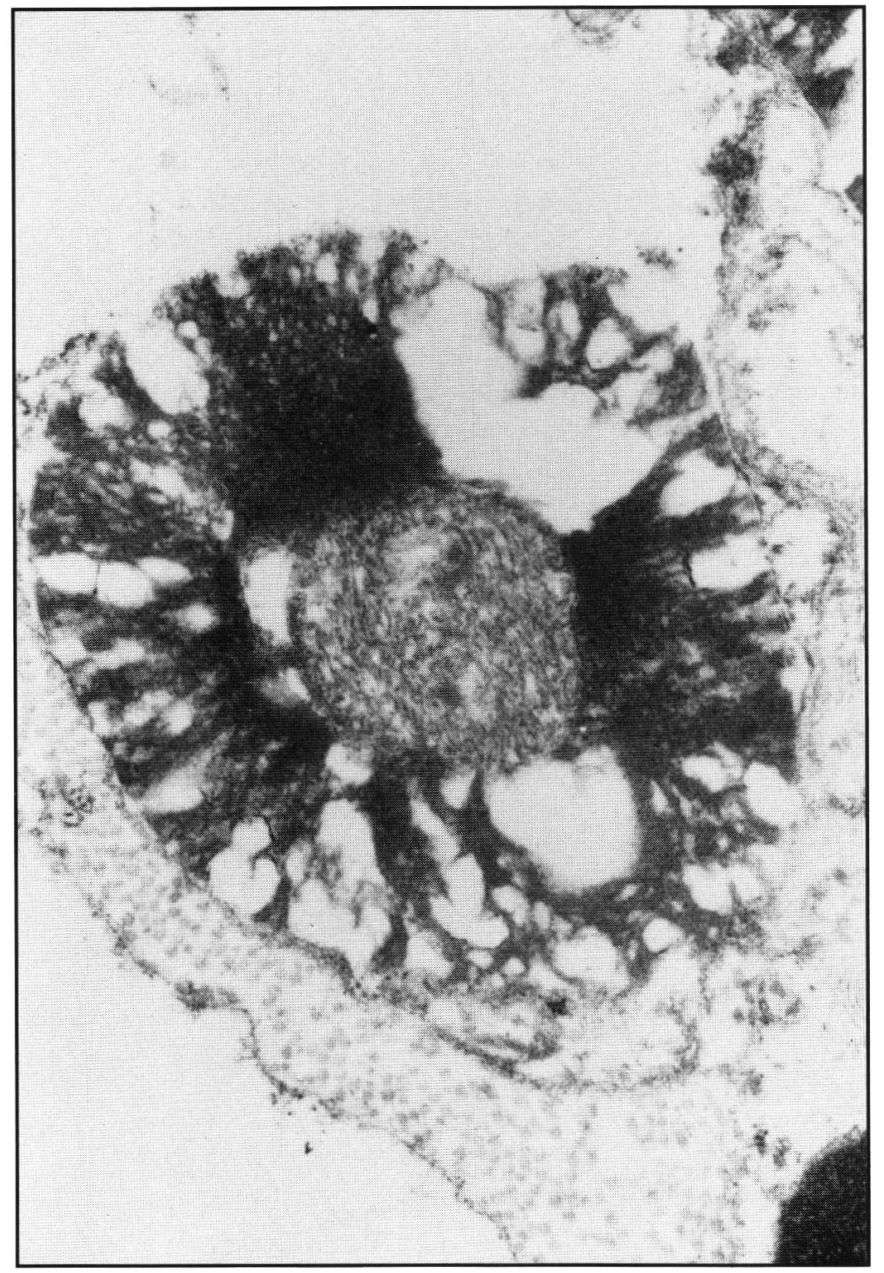

Figure $3-A \& B$ : Electron microscopy of cervical spinal cord (lateral column) demonstrates vacuolation of the myelin surrounding an axon (A $x$ $22,000, B \times 29,000$ ). 


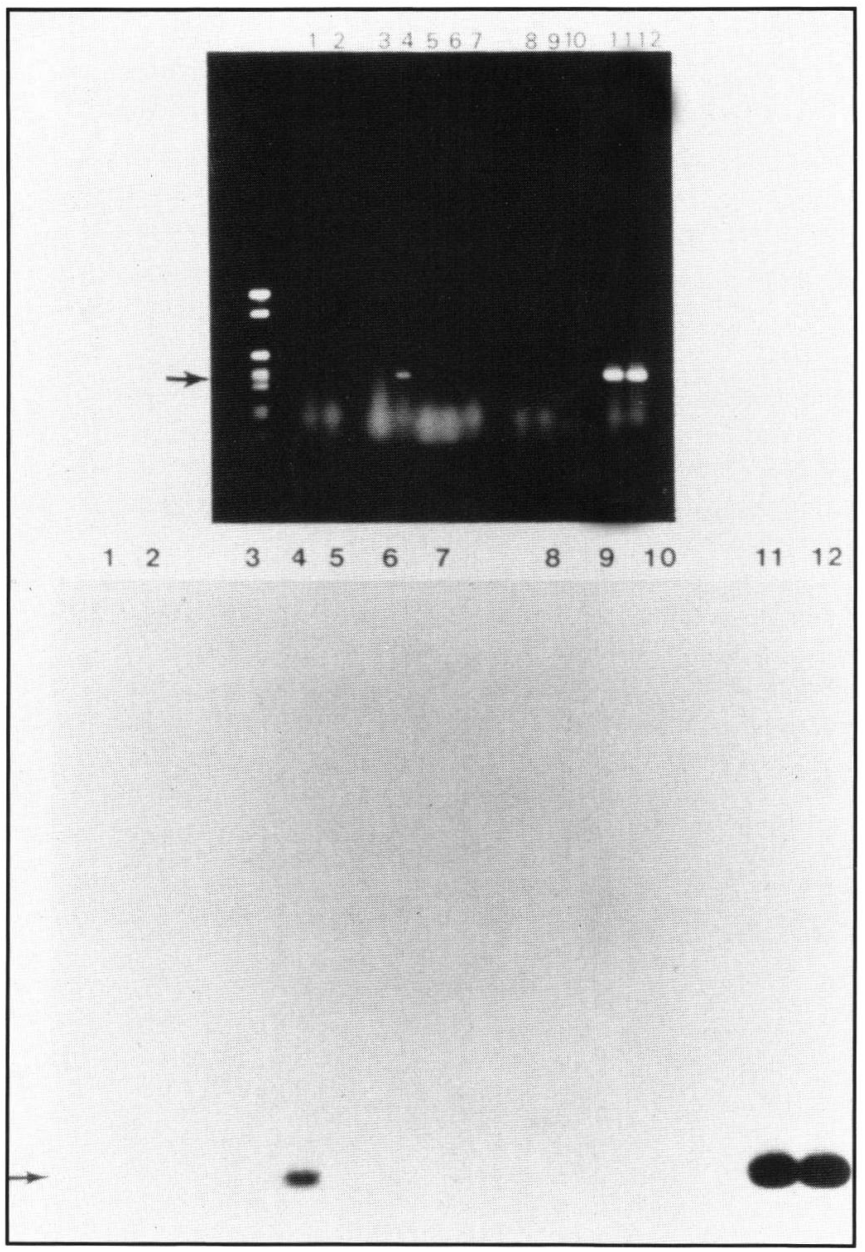

Figure 4-Panel A shows the ethidium bromide gel of the PCR amplification products. Panel $B$ shows the results of the southern blot analysis of this same gel following a 3 hour exposure to $x$-ray film. The arrows in Panel $A$ and $B$ indicate the position of the expected 623 base pair amplification product:

Lane I - normal spinal cord

Lane 2 - normal brain

Lane 3 - TSP thoracic spinal cord

Lane 4 - TSP cervical spinal cord

Lane 5 - TSP cerebral cortex

Lane 6 - TSP midbrain

Lane 7 - -

Lane 8 - water control

Lane 9,10 - sham DNA extraction controls for the block samples shown

Lane 11 - PBL from an HTLV-I seropositive TSP patient

Lane 12 - HTLV-I infected HUT 102 cells secondary axonal loss. Our findings also strengthen the association between HTLV-1 infection and the pathogensis of Tropical Spastic Paraparesis.

\section{ACKNOWLEDGEMENTS}

The authors thank Dr. J. Deck of the Toronto General Hospital for providing the necessary tissues. The authors thank Elaine Kinghorn for providing excellent technical assistance. G.A.D. and G.P.A.R. are funded as Ontario Ministry of Health Career Scientists. This work was supported in part by the MS Society of Canada.

\section{REFERENCES}

1. Jacobsen S, Raine CS, Mingioli ES, et al. Isolation of an HTLV-1 like restrovirus from patients with tropical spastic paraparesis. Nature 1988; 331: 540-543.

2. Bhagavati S, Ehrlich G, Kula R, et al. Detection of human T-cell lymphoma/leukemia virus type I DNA and antigen in spinal fluid and blood of patients with chronic progressive myelopathy. N Engl J Med 1988; 318: 1141-1147.

3. Gessain A, Barin F. Vernant J, et al. Antibodies to human T. lyumphotropic virus type-I in patients with tropical spastic pariparesis. Lancet 1985; 2: 407-410.

4. Roman GC, Spencer PS, Schoenberg BS. Tropical spastic paraparesis in the Seychelle Islands: a clinical and case-control neuroepidemiologic study. Neurology 1987; 37: 1323-1328.

5. Roman GC, Roman LN, Spencer PS, et al. Tropical spastic paraparesis: a neuroepidemiological study in Columbia. Ann Neurol 1985; 17: 361-365.

6. Osame $\mathrm{M}$, Matsamuto $\mathrm{M}$, Usuku K, et al. Chronikc progressive myelopathy associated with elevated antibodies to HTLV-I and adult T-cell leukemia-like cells. Ann Neurol 1987; 21: 117-122.

7. Roman GC. The neuroepidemiology of tropical spastic paraparesis. Ann Neurol 1988; 23 (supp): S113-120.

8. Robertson WB and Cruickshank EK. Jamaican (tropical) myeloneuropathy. In: Minckler J, ed. Pathology of the Nervous System. New York, McGraw-Hill 1972; 2466-2476.

9. Piccardo P, Ceroni M, Rodgers-Johnson P, et al. Pathological and immunological observations on tropical spastic paraparesis in patients from Jamaica. Ann Neurol 1988; 23 (suppl): S156-S160.

10. Dubeau L, Chandler LA, Gralow JR, et al. Southern blot analysis of DNA extracted from formalin-fixed pathology specimens. Cancer Res 1986; 46: 2964-2969.

11. Moore GRW, Traugott U, Scheinberg LC, et al. Tropical spastic paraparesis: a model of virus-induced, cytotoxic T-cell-mediated demyelination? Ann Neurol 1989; 26: 523-530.

12. Power C, Weinshenker GB, Dekaban GA, et al. HTLV-I associated myelopathy in Canada: clinical and diagnostic features. Can J Neurol Sci 1989; 16: 330-335.

13. Saiki R, Gelfand D, Stoffel $S$, et al. Primer-directed enzymatic amplification of DNA with a thermostable DNA polymerase. Science 1988; 239: 487-494.

14. Reed KC and Mann DA. Rapid transfer of DNA from agarose gels to nylon membranes. Nucleic Acids Res. 1983; 13: 7207-7221.

15. Liberski PP, Rodgers-Johnson P, Char G, et al. HTLV-1 like viral particles in spinal cord cells in Jamaican tropical spastic paraparesis. Ann Neurol 1988; 24 (suppl): S185-S187. 